\title{
The effect of tillage system and use of a paraplow on weed flora in a semiarid soil from central Spain
}

\author{
J DORADO \& C LÓPEZ-FANDO \\ Centro de Ciencias Medioambientales, CSIC, Madrid, Spain
}

Received 1 February 2006

Revised version accepted 19 May 2006

\section{Summary}

Field experiments were conducted to study weed population shifts in long-term conservation tillage systems. The objectives of this study were to determine weed community abundance, diversity and composition on conventional tillage (CT), minimum tillage (MT), no-tillage with paraplow (ZT) and no-tillage (NT) systems, and to identify species that are associated with specific tillage systems. The paraplow is a subsoiling technique that results in a deep loosening of the soil, in order to alleviate compaction in certain soils where NT is practiced. The results showed significant differences in both the composition and the abundance of weeds, depending on the tillage systems. Weed diversity, species richness and Shannon's diversity and evenness indices were higher under the conservation tillage systems than in the CT system. In addition, various weed species were associated with reduced tillage systems. For instance, Anthemis arvensis, Hirschfeldia incana and Lolium rigidum became more prevalent in the NT system, whereas Chenopodium album and Filago pyramidata dominated in the ZT system. Therefore, the application of a paraplow treatment changed the weed community in the NT system. Other weed species, such as Capsella bursa-pastoris and Torilis nodosa, dominated in all three conservation tillage systems, whereas soil disturbance by mouldboard ploughing favoured species such as Polygonum aviculare and Phalaris paradoxa.

Keywords: conservation tillage, semiarid environment, weed diversity, relative abundance, weed associations.

Dorado J \& LóPEz-FAndo C (2006) The effect of tillage system and use of a paraplow on weed flora in a semiarid soil from central Spain. Weed Research 46, 424-431.

\section{Introduction}

The use of conservation tillage techniques in semiarid soils in southern Europe has evolved over the last decades, largely as an effort to reduce soil erosion, as well as to increase soil moisture availability and crop yield. One of the main concerns with the adoption of conservation tillage practices is potential weed management problems. Another important limiting factor to the use of no-tillage (NT) in semiarid areas is the possibility of soil compaction (López-Fando \& Almendros, 1995). Tillage with a paraplow is a partial width tillage system, which has been known to be particularly effective for loosening the soil, while leaving much of the plant residue on the soil surface (Pierce et al., 1992). Several authors have reported benefits associated with the periodic use of a paraplow in rotation with NT, including reduced soil compaction and increased water availability to plants (Parker et al., 1989; Sojka et al., 1997).

The adoption of conservation tillage practices that include NT or minimum tillage (MT) has been shown to lead to shifts in weed communities (Bilalis et al., 2001; Blackshaw et al., 2001; Shrestha et al., 2002; Tørresen et al., 2003; Légère \& Samson, 2004; Thomas et al., 2004; Primot et al., 2006). Several authors have reported an increase in annual grasses, perennial weeds and winddispersed species with reduced tillage (Menalled et al., 2001; Tørresen et al., 2003). At the same time, the literature provides other examples where weed community dynamics showed no consistent response to reduced tillage (Derksen et al., 1993; McCloskey et al., 1996). 
Thus, further studies are needed to understand the influence of conservation tillage practices on weed flora community, paying special attention to new reduced tillage practices such as the use of paraplow subsoiling in NT systems.

The diversity of species within weed communities is of agronomic significance because of it is indicative of the response of weed species to soil management. Community diversity changes associated with the adoption of conservation tillage practices are of particular relevance, as a reduction in the use of tillage sometimes favours more difficult-to-control species (Derksen et al., 1993). Nevertheless, governments as well as nongovernmental organizations have begun promoting increased biodiversity in agricultural ecosystems, considering, among other things, the use of arable weeds as indicator organisms to evaluate management effects on wildlife diversity in arable fields (Albrecht, 2003). In any case, weeds are an important variable in crop production, both agronomically and ecologically, and appropriate diversity indices should be used in assessing shifts in weed communities caused by changes in cultural practices. Previous studies have made use of diversity indices which incorporate aspects of species richness and evenness (e.g. Derksen et al., 1995; Bilalis et al., 2001; Van Gessel et al., 2004; Légère et al., 2005).

A long-term multidisciplinary study was set up in 1987 to determine the influence of tillage practices on soil physical and chemical properties, crop yields, weed densities and weed species shift in a cereal/legume rotation on a semiarid soil in central Spain. This article only presents aspects that relate to the weed community after introducing paraplow-subsoiling treatments into NT plots in 2003. The specific objectives of the study were to compare weed community abundance, diversity and composition among conventional tillage (CT), MT, no-tillage with paraplow (ZT) and NT systems, and to identify weed species associated with specific tillage systems.

\section{Materials and methods}

\section{Experimental site}

The field studies were conducted at the CSIC experimental farm 'La Higueruela' (UTM coordinates: zone 30 $4434290 \mathrm{mN} 377738 \mathrm{mE}$ ) under semiarid continental climate (average temperatures of $6^{\circ} \mathrm{C}$ and $23^{\circ} \mathrm{C}$ in winter and summer, respectively; mean annual rainfall c. $400 \mathrm{~mm}$, with an extended dry season from June to September) in the cereal-producing area of central Spain. The soil type is a Calcic Haploxeralf with loamsandy texture $(78.3 \%$ sand, $8.2 \%$ silt, $13.5 \%$ clay, c. $1 \%$ organic matter and $\mathrm{pH} 6)$.

\section{Experimental procedures}

An experiment designed to compare the effect of different tillage systems on weed, crop and soil characteristics was established in 1987. Changes to the experimental design were made in 2003 by adding paraplow-subsoiling treatments to the NT plots, which were becoming compacted. The experiment was arranged in a randomised complete block design with three replications. Plot size was $40 \mathrm{~m}$ by $9 \mathrm{~m}$. The tillage treatments consisted of: (i) conventional plough tillage $(\mathrm{CT})$, i.e. tilling the soil with mouldboard plough to a $25-30 \mathrm{~cm}$ depth; (ii) chisel (minimal) tillage (MT), i.e. chiselling the soil to a depth $15-20 \mathrm{~cm}$; (iii) no-tillage (NT), i.e. implementing direct drilling, spraying the volunteer plants and weeds with glyphosate (Roundup ${ }^{\circledR} 400$ PreSiembra $^{\text {TM }}$, isopropylamine salt, $400 \mathrm{~g}$ acid equivalent (a.e.) $\mathrm{L}^{-1}$, SL, Monsanto Agricultura España, Madrid, Spain) at $800 \mathrm{~g}$ a.e. $\mathrm{ha}^{-1}$ in $150 \mathrm{~L} \mathrm{ha}^{-1}$ water at a pressure of $200 \mathrm{kPa}$ before seeding with a triple-disk seed drill; and (iv) zonetillage (ZT), i.e. subsoiling with a paraplow to a depth of $30 \mathrm{~cm}$ in 2003 and 2005, in order to alleviate soil compaction in plots which were previously NT plots. In these plots the crops were direct drilled as in NT. In 2004, the ZT plots were returned to NT.

The crop sequence was grey pea (Pisum sativum L. cv. Gracia)/barley (Hordeum vulgare L. cv. Volley). Previous crop rotation (up to 2002) included chick-pea (Cicer arietinum L. cv. Inmaculada) and barley in a 2-year rotation. Grey pea was seeded on 25 November 2002 and on 29 November 2004 at a rate of $100 \mathrm{~kg} \mathrm{ha}^{-1}$ in $30-\mathrm{cm}$ rows. No inter-row cultivation was performed on the grey pea crop. Weed control in the grey peas was attained by the pre-emergence application of pendimethalin (Stomp LE, $330 \mathrm{~g}$ a.i. $\mathrm{L}^{-1}$, EC, BASF, Española, Tarragona, Spain) at $1320 \mathrm{~g}$ a.i. $\mathrm{ha}^{-1}$ in $300 \mathrm{~L} \mathrm{ha}^{-1}$ water at a pressure of $200 \mathrm{kPa}$. The grey peas were harvested on 21 May 2003 and on 25 May 2005. Barley was seeded on 24 November 2003 at $150 \mathrm{~kg} \mathrm{ha}^{-1}$ in $15-\mathrm{cm}$ rows. At sowing of barley crop, $300 \mathrm{~kg} \mathrm{ha}^{-1}$ of NPK fertiliser (15-15-15) was applied. Ammonium nitrate was broadcast at $54 \mathrm{~kg}$ $\mathrm{N} \mathrm{ha}^{-1}$ in early spring on the barley. Spring weed control consisted of diclofop (Iloxan, $360 \mathrm{~g}$ a.i. $\mathrm{L}^{-1}$, EC, Bayer CropScience, Valencia, Spain) at $540 \mathrm{~g}$ a.i. $\mathrm{ha}^{-1}$ and ioxynil (Totril, $225 \mathrm{~g}$ a.i. $\mathrm{L}^{-1}$, EC, Bayer) at $450 \mathrm{~g}$ a.i. $\mathrm{ha}^{-1}$ in $300 \mathrm{~L}$ of water $\mathrm{ha}^{-1}$ at a pressure of $200 \mathrm{kPa}$, when the weeds were at the three- to four-leaf growth stage. Barley was harvested on 24 June 2004.

Weeds and crop yield data for this study were collected from 2003 to 2005. Weed counts were taken once per month from March to June. The data presented here come from observations made on 13 May 2003, 6 May 2004 and 15 May 2005. Weeds were counted within 16 randomly selected $0.0625-\mathrm{m}^{2}$ areas in each plot. Within 
each plot, four 2-m long centre rows were sampled at harvest time in order to estimate grain and dry matter production $\left(\mathrm{g} \mathrm{m}^{-2}\right)$ in barley and grey pea respectively.

\section{Statistical analysis}

The analysis of weed density, weed species richness, diversity and evenness indices and crop yield as influenced by tillage treatment was performed separately for every year (crop) by using analysis of variance. Differences among the treatment means were determined by the standard error of the difference between means.

In order to reduce the problems caused by a nonuniform weed distribution (Derksen et al., 1995), the composition of the weed flora was analysed by calculating the relative abundance of each species in each plot as follows:

Relative abundance $=\frac{\text { Relative density }+ \text { Relative frequency }}{2}$

where relative density was calculated as the number of weed plants for a given species within the 16 quadrats per plot divided by the total number of weeds within the plot. Relative frequency was calculated as the proportion of the quadrats in which the species was present per plot divided by the total frequency of all species. To meet the assumptions of parametric analysis, weed density and relative abundance values were transformed before analysis with a $\log (x+1)$ transformation.

Relative abundance data were subjected to multivariate analyses to examine associations of weed species with the different tillage systems. The variables processed were the weed species significantly affected by the tillage treatments (in addition, backward automatic variable selection was used), whereas the samples were the different tillage systems. Correspondence analysis (two-way table, no supplementary observations; ITCF, 1988) was performed to examine the relationship between samples and the descriptors responsible for their variability. The program output draws samples and variables as points in the two dimensional space defined by axes calculated as linear combinations of the original set of variables. These synthetic axes accounted for a considerable portion of the total variance (inertia) of the whole set of variables and, in this case, can be used for recognizing weed composition patterns as a function of the tillage system.

Diversity $\left(H^{\prime}\right)$ and evenness $(E)$ Shannon indices (Magurran, 1988) were determined by considering the data from the 16 quadrats per plot as follows:

$$
H^{\prime}=\left(N \log N-\sum n \log n\right) N^{-1}
$$

where $H^{\prime}$ measures species diversity through proportional abundance of species, with a higher value signifying greater diversity, $N$ is the total weed population density per square metre and $n$ is the population of each weed species found in this area; and

$$
E=H^{\prime}(\ln N)^{-1}
$$

where $E$ is the relationships between the observed number of species and the maximum number of species, with a higher value indicating greater uniformity between species abundance, $H^{\prime}$ is the Shannon diversity index and $N$ is the total weed population density per square metre.

\section{Results and discussion}

The density and relative abundance of individual species varied from year to year and among tillage systems. A total of 25, 20 and 20 weed species were identified in the spring assessment in 2003, 2004 and 2005 respectively.

\section{Total weed density}

The highest weed density across years was found in the NT system, whereas the lowest was found in the CT system (Table 1). Weed densities in the MT system showed intermediate values between CT and NT systems, with significant differences among the three tillage treatments in 2004 and 2005. No statistical differences were found between $\mathrm{ZT}$ and NT and MT in the two initial years (2003 and 2004). However, in 2005 total weed population densities in ZT were significantly lower than in NT. These results are in agreement with other studies that reported greater weed densities under NT than under CT systems (Blackshaw et al., 1994; Tørresen et al., 2003; Primot et al., 2006) and intermediate values in the case of MT systems (Bilalis et al., 2001). There was a $30-35 \%$ reduction in soil cover in the ZT versus the NT plots (data not shown) and cover levels were lowest on treatments with the lowest weed densities (e.g. MT and CT), suggesting a possible mechanistic association between cover level and weed density.

\section{Specific weed densities}

In this study, many of the weed species most affected by tillage treatments had a winter annual life cycle coinciding with that of the grey pea and barley crops, except the summer annuals Amaranthus albus L. and Chenopodium album L., and the biennials Anchusa italica Retz, Hirschfeldia incana (L.) Lagr.-Foss. and Lactuca serriola $\mathrm{L}$.

All three conservation tillage systems favoured weed growth, with a greater number of weed species and higher densities than in the CT system (Table 1). In fact, the highest weed densities for Anthemis arvensis L., Lolium rigidum Gaudin and $H$. incana (the latter in the 2 years 


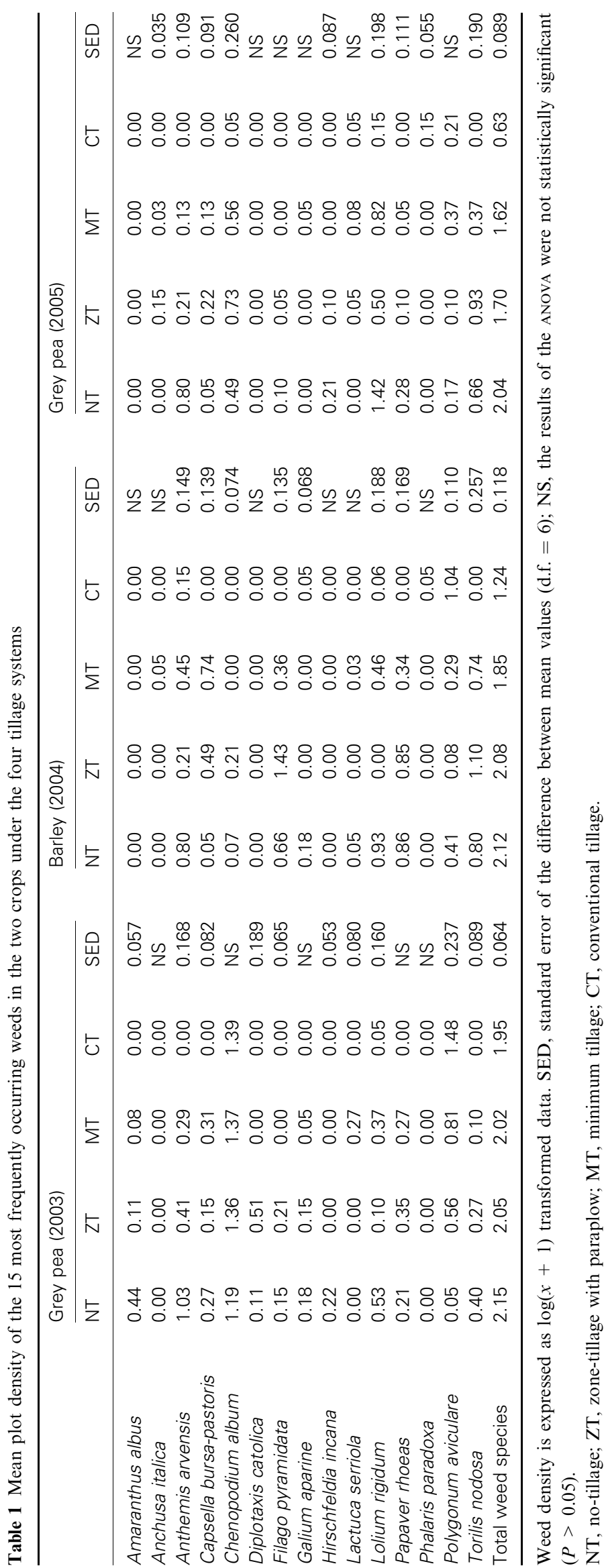


corresponding to the grey pea crop), were found in NT plots. A. arvensis and L. rigidum may be well suited to the NT system because of small seed size and an adaptation to surface germination. García Baudín (1988) observed the greatest emergence of L. rigidum from seeds near the soil surface (approximately $1 \mathrm{~cm}$ deep). As a general rule, weed species with small sized seeds may recruit more readily in fields where the cultural practices keep seeds at or near the soil surface (Froud-Williams et al., 1984). On the other hand, biennial weeds such as $H$. incata may increase in NT systems because the root system is not disturbed and the herbicides used to control annual weeds may not be effective on established perennial plants (Buhler et al., 1994).

Weed density of $C$. album and Filago pyramidata L. was significantly higher in ZT than in the other three tillage systems in 2 of the 3 years. For both of the species, differences based on the crop within the rotation were observed: the density of $C$. album was greater in grey pea crops, whereas $F$. pyramidata was found mainly in the cereal crop in the second year.

No statistically significant differences were found between the NT and ZT systems for Papaver rhoeas L. density. Apparently, the population of this weed species was not affected by the use of the paraplow. Nevertheless, the densities of $P$. rhoeas were significantly higher in NT and ZT systems than in MT and CT systems, especially in the barley crop. Similar studies performed in central Spain by Navarrete et al. (2005) showed that $P$. rhoeas was better adapted to NT than to mouldboard ploughed treatments.

The increase in the weed density of Capsella bursapastoris (L.) Medik. and Torilis nodosa (L.) Gaertn. was linked to conservation tillage practices, with the lowest densities found in the CT system. Légère and Samson (1999) explained the association of C. bursa-pastoris with no-till as a consequence of the shift from an annual to a winter annual habit in reduced tillage systems. With respect to $T$. nodosa, Chancellor and Froud-Williams (1986) and Dorado et al. (1999) noted that some species from the same family (Apiaceae), which are commonly found along borders of fields or in non-cultivated areas, can invade NT plots.

In contrast, densities of Phalaris paradoxa L. (in the third year) and Polygonum aviculare L. (in the first 2 years) were higher in the CT system than in the three conservation tillage systems. Other authors have also noted an association between $P$. aviculare and CT systems (Chancellor, 1985; Derksen et al., 1993).

\section{Species richness, weed diversity and evenness}

Species richness was significantly lower in the CT system than in the conservation tillage systems in all 3 years
Table 2 Richness (number of species per plot), diversity (Shannon's $H^{\prime}$ index) and evenness (Shannon's $E$ index) for all weed species present in the two crops under the four tillage systems

\begin{tabular}{|c|c|c|c|}
\hline & $\begin{array}{l}\text { Number } \\
\text { of species }\end{array}$ & Shannon's $H^{\prime}$ & Shannon's $E$ \\
\hline \multicolumn{4}{|c|}{ Grey pea (2003) } \\
\hline NT & 11.7 & 1.58 & 0.49 \\
\hline $\mathrm{ZT}$ & 9.7 & 1.38 & 0.43 \\
\hline MT & 8.3 & 1.45 & 0.45 \\
\hline CT & 3.0 & 0.65 & 0.20 \\
\hline SED & 0.88 & 0.149 & 0.046 \\
\hline \multicolumn{4}{|c|}{ Barley (2004) } \\
\hline NT & 7.7 & 1.46 & 0.49 \\
\hline $\mathrm{ZT}$ & 5.7 & 1.42 & 0.47 \\
\hline MT & 8.2 & 1.64 & 0.55 \\
\hline $\mathrm{CT}$ & 3.0 & 0.64 & 0.21 \\
\hline SED & 0.76 & 0.115 & 0.045 \\
\hline \multicolumn{4}{|c|}{ Grey pea (2005) } \\
\hline NT & 8.3 & 1.45 & 0.48 \\
\hline $\mathrm{ZT}$ & 6.0 & 1.44 & 0.48 \\
\hline MT & 6.5 & 1.36 & 0.45 \\
\hline $\mathrm{CT}$ & 3.0 & 1.00 & 0.33 \\
\hline SED & 0.72 & 0.148 & 0.041 \\
\hline
\end{tabular}

SED, standard error of the difference between means (d.f. $=6$ ). NT, no-tillage; ZT, zone-tillage with paraplow; MT, minimum tillage; $\mathrm{CT}$, conventional tillage.

(Table 2). The comparison among the reduced tillage systems showed a tendency towards reduced species richness in the ZT plots compared with the NT plots. In the 2 years in which grey peas were grown, weed species richness in the MT system was lower than in the NT system.

Shannon's $H^{\prime}$ diversity index was significantly lower in the CT system than in the conservation tillage systems. Diversity was similar among the three conservation tillage systems (Table 2). These results corroborate the species richness results. Thus differences in weed diversity as a function of tillage management were apparent in relation to weed community structure, as well as in relation to species richness. In the CT system, only one species ( $P$. aviculare) became dominant within the community, whereas in the conservation tillage systems a number of species were dominant, all with similar relative abundances (Table 3 ). The community evenness (Shannon's $E$ index) results were similar to the diversity results, with the lowest values in the CT system, indicating that CT tended to be dominated by a few species. No significant differences in community evenness were found among the three conservation tillage systems. The effects of tillage on weed communities have been previously discussed in the literature, and often, conflicting results have been presented, possibly as a result of community fluctuations rather than consistent changes in community composition (Derksen et al., 1993; Légère et al., 2005). In order to counter this 
Table 3 Average value of the relative abundance for the main species (values higher than 9) in the different tillage systems in the 2003 to 2005 survey

\begin{tabular}{|c|c|}
\hline \multicolumn{2}{|l|}{ No-tillage } \\
\hline Lolium & $55(25,48,92)$ \\
\hline Anthemis & $44(45,44,43)$ \\
\hline Chenopodium & $36(70,7,32)$ \\
\hline Torilis & $34(21,42,37)$ \\
\hline Papaver & $28(15,56,14)$ \\
\hline Filago & $20(10,38,12)$ \\
\hline Polygonum & $14(4,23,14)$ \\
\hline Capsella & $9(14,6,6)$ \\
\hline \multicolumn{2}{|c|}{ Zone-tillage with paraplow } \\
\hline Torilis & $53(20,62,76)$ \\
\hline Chenopodium & $53(89,16,55)$ \\
\hline Filago & $37(14,89,8)$ \\
\hline Papaver & $30(23,56,11)$ \\
\hline Anthemis & $23(25,21,23)$ \\
\hline Capsella & $21(9,36,18)$ \\
\hline Lolium & $17(7,0,45)$ \\
\hline Polygonum & $17(31,10,11)$ \\
\hline Diplotaxis & $9(26,0,0)$ \\
\hline \multicolumn{2}{|l|}{ Minimum tillage } \\
\hline Lolium & $46(25,35,76)$ \\
\hline Chenopodium & $44(78,0,55)$ \\
\hline Polygonum & $39(50,27,40)$ \\
\hline Capsella & $31(24,49,19)$ \\
\hline Torilis & $31(8,48,36)$ \\
\hline Anthemis & $24(20,34,17)$ \\
\hline Papaver & $16(18,23,6)$ \\
\hline Anagallis & $13(24,14,0)$ \\
\hline Lactuca & $11(18,3,13)$ \\
\hline Filago & $10(0,30,0)$ \\
\hline \multicolumn{2}{|c|}{ Conventional tillage } \\
\hline Polygonum & $134(138,181,84)$ \\
\hline Chenopodium & $48(116,0,26)$ \\
\hline Lolium & $38(14,20,79)$ \\
\hline Phalaris & $25(0,17,57)$ \\
\hline Anagallis & $14(17,24,0)$ \\
\hline Anthemis & $14(0,41,0)$ \\
\hline Avena & $9(0,0,26)$ \\
\hline Lactuca & $9(0,0,26)$ \\
\hline
\end{tabular}

Species name of the weed genus: Anagallis arvensis; Anthemis arvensis; Avena sterilis; Capsella bursa-pastoris; Chenopodium album; Diplotaxis catolica; Filago pyramidata; Lactuca serriola; Lolium rigidum; Papaver rhoeas; Phalaris paradoxa; Polygonum aviculare; Torilis nodosa.

In parentheses, the relative abundances for weed species sampled in May 2003, 2004 and 2005 respectively.

problem, long-term experiments like the present study need to be conducted, although here we present only 3 years of data within the longer timeframe of the study. Some previous long-term studies (Blackshaw et al., 2001; Mulugeta et al., 2001) agree with our findings and show greater numbers of weed species in NT versus mouldboard ploughed systems, but these studies involved different cropping systems in different locations. In contrast with our results, some other studies did not find any increase in species richness in the MT treatments compared with mouldboard ploughed systems (Bilalis et al., 2001; Blackshaw et al., 2001; Mulugeta et al., 2001).

\section{Tillage and weed associations}

The relative abundance of individual species varied for the different tillage systems (Table 3). The ranking of species also differed among the three conservation tillage systems: L. rigidum was the most abundant species under the NT and MT systems, whereas T. nodosa was the most abundant species under the ZT system. On the other hand, $P$. aviculare abundance was highest in CT plots. Other weed species were also associated with specific tillage systems: A. arvensis ranked second in NT, $F$. pyramidata ranked third in ZT, $P$. aviculare ranked third in MT and L. rigidum ranked third in CT. In contrast, the relative abundance of C. album was similar in all tillage treatments. In fact, this species ranked second in CT, MT and ZT systems and third in NT system.

Differences in weed communities as a function of tillage systems can also be observed when an overall analysis of community compositional features is carried out by using correspondence analysis (Fig. 1). In general, the species that differentiated the weed communities according to tillage systems were species with high or medium rank in relative abundance (Table 3). For instance, $P$. aviculare was ranked first and $P$. paradoxa was ranked fourth in $\mathrm{CT}$ and both species were strongly

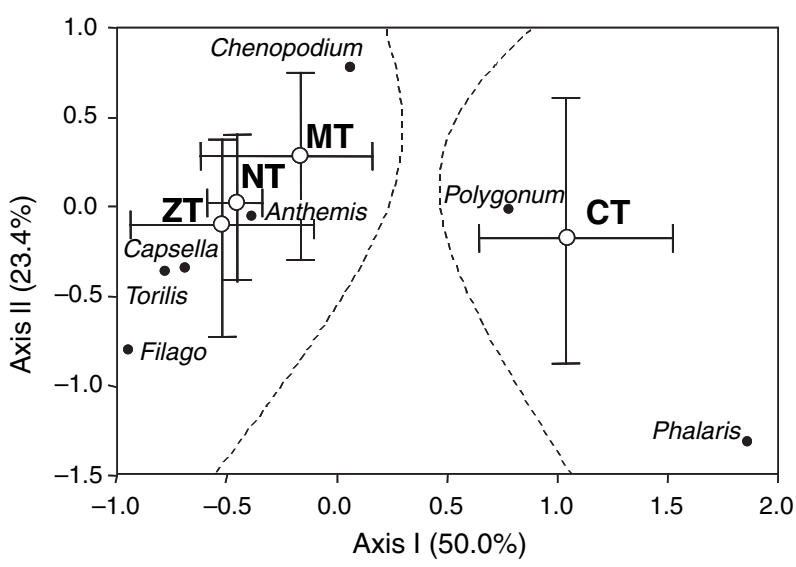

Fig. 1 Correspondence analysis showing the association of weed species with tillage systems (bold labels): NT, no-tillage; ZT, zonetillage with paraplow; MT, minimum tillage; CT, conventional tillage. Species names for the weed genus: Anagallis arvensis; Anthemis arvensis; Capsella bursa-pastoris; Chenopodium album; Filago pyramidata; Phalaris paradoxa; Polygonum aviculare; Torilis nodosa. Error bars indicate the variability ranges defined by triplicate runs; average values (centroids) are drawn with circles. The percentage of the total variance accounted for by the two first components is shown in the corresponding axes. 
associated with that tillage system, but they were not ranked within the most abundant species in the other tillage systems. As expected, the scores for the three conservation tillage systems formed a cluster characterized by weed species strongly related to these tillage systems. In fact, $A$. arvensis was ranked second in the NT system, $T$. nodosa and $F$. pyramidata were ranked second and third, respectively, in the ZT system, and C. bursa-pastoris was ranked fourth in the MT system. Surprisingly, one species (C. album) with similar relative abundance in all the studied tillage systems, was shown to be a discriminatory species associated with the reduced tillage systems, based chiefly on its differences in weed abundance during the last 2 years (see Table 1). L. rigidum, the most abundant species in the $\mathrm{NT}$ and the MT systems, did not contribute to the community discrimination, probably because its relative abundance in the CT system was high.

\section{Crop yields}

Tillage had significant effects on crop yields (Table 4). In 2003 and 2004, crop yields were lower in NT compared with the other tillage systems, probably because of the higher weed densities in this system (Table 1). Nevertheless, considering that no significant differences in weed density were found between NT and ZT, the higher crop yields obtained in ZT could be the result of improvements in soil properties and increases in soil moisture content or availability (López-Fando \& Dorado, 2005). The effects of ZT have mainly been observed in the year following paraplowing, although the improvement in crop yields were not as great in 2004. No significant differences were found in either grey peas or barley yields among ZT, MT and CT systems.

Although the paraplow was used again in 2005, no significant differences in crop yields among tillage systems were found in this year. This may be due to the unusually low rainfall registered at the experimental

Table 4 Average crop yields $\left(\mathrm{g} \mathrm{m}^{-2}\right)$ under the four tillage systems at the CSIC experimental farm 'La Higueruela', central Spain

\begin{tabular}{llll}
\hline & $\begin{array}{l}\text { 2003 Grey pea } \\
\text { (dry matter) }\end{array}$ & $\begin{array}{l}\text { 2004 Barley } \\
\text { (grain) }\end{array}$ & $\begin{array}{l}\text { 2005 Grey pea } \\
\text { (dry matter) }\end{array}$ \\
\hline NT & 387 & 357 & 393 \\
ZT & 561 & 417 & 397 \\
MT & 471 & 414 & 417 \\
CT & 458 & 451 & 393 \\
SED & 52.8 & 34.6 & NS \\
\hline
\end{tabular}

SED, standard error of the difference between mean values (d.f. $=$ $6)$. NS, the results of the ANOVA were not statistically significant $(P>0.05)$.

NT, no-tillage; ZT, zone-tillage with paraplow; MT, minimum tillage; $\mathrm{CT}$, conventional tillage. farm in $2005(282 \mathrm{~mm})$ compared with previous years (499 $\mathrm{mm}$ in 2003 and $593 \mathrm{~mm}$ in 2004).

In conclusion, this study showed changes in weed flora associated with changes in tillage practice. Conservation tillage systems resulted in increased weed diversity compared with conventional mouldboard plough-based tillage systems. Some species, such as C. bursa-pastoris and T. nodosa, were more prevalent in the reduced tillage systems (NT, ZT and MT), while two weed species ( $P$. aviculare and $P$. paradoxa) were more prevalent in the CT system. The results of this study also demonstrated that even in a relatively short time (3 years), weed population shifts may occur with the use of a paraplow in NT systems. For example, although $P$. rhoeas was associated with NT systems whether or not the paraplow was used, A. arvensis, $H$. incana and L. rigidum were more prevalent when the paraplow was not used and $C$. album and $F$. pyramidata were more prevalent when it was used.

\section{Acknowledgements}

This research was funded by the Spanish CICyT (project AGL2002-04186-CO3-02) and by the Junta de Comunidades Castilla-La Mancha (project 2004X802-3). The authors thank Dr César Fernández-Quintanilla for his valuable comments on the manuscript.

\section{References}

Albrecht H (2003) Suitability of arable weeds as indicator organisms to evaluate species conservation effects of management in agricultural ecosystems. Agriculture, Ecosystems \& Environment 98, 201-211.

Bilalis D, Efthimiadis P \& Sidiras N (2001) Effect of three tillage systems on weed flora in a 3-year rotation with four crops. Journal of Agronomy and Crop Science 186, 135-141.

Blackshaw RE, Larney FO, Lindwall CW \& Kozub GC (1994) Crop rotation and tillage effects on weed populations on the semi-arid Canadian prairies. Weed Technology 8, 231-237.

Blackshaw RE, Larney FJ, Lindwall CW, Watson PR \& Derksen DA (2001) Tillage intensity and crop rotation affect weed community dynamics in a winter wheat cropping system. Canadian Journal of Plant Science 81, 805-813.

Buhler DD, Stoltenberg DE, Becker RL \& Gunsolus JL (1994) Perennial weed populations after 14 years of variable tillage and cropping practices. Weed Science 42, 205-209.

Chancellor RJ (1985) Changes in the weed flora of an arable field cultivated for 20 years. Journal of Applied Ecology 22, 491-501.

Chancellor RJ \& Froud-Williams RJ (1986) Weed problems of the next decade in Britain. Crop Protection 5, 66-72.

Derksen DA, Lafond GP, Thomas AG, Loeppky HA \& Swanton CJ (1993) Impact of agronomic practices on weed communities: tillage systems. Weed Science 41, 409-417.

Derksen DA, Thomas AG, Lafond GP, Loeprky HA \& Swanton CJ (1995) Impact of post-emergence herbicides on weed 
community diversity within conservation-tillage systems. Weed Research 35, 311-320.

Dorado J, Del Monte JP \& López-Fando C (1999) Weed seed bank response to soil management in semi-arid agrosystems. Weed Science 47, 67-73.

Froud-Williams RJ, Chancellor RJ \& Drennan DSH (1984) The effects of seed burial and soil disturbance on emergence and survival of arable weeds in relation to minimal cultivation.

Journal of Applied Ecology 21, 629-641.

García Baudín JM (1988) Gramíneas adventicias en los cereales de invierno españoles. Especies adventicias del género Lolium en los cereales (trigo y cebada) españoles. Fascículo Phytoma España 2, 1-55.

ITCF (1988) STAT-ITCF. Manuel d'Utilisation, Impressions Atelier, Paris, France.

LÉGÈre A \& SAMSON N (1999) Relative influence of crop rotation, tillage, and weed management on weed associations in spring barley cropping systems. Weed Science 47, $112-122$.

LÉGÈRE A \& SAMSON N (2004) Tillage and weed management effects on weeds in barley-red clover cropping systems. Weed Science 52, 881-885.

Légère A, Stevenson FC \& Benoit DL (2005) Diversity and assembly of weed communities: contrasting responses across cropping systems. Weed Research 45, 303-315.

López-FAndo C \& Almendros G (1995) Interactive effects of tillage and crop rotations on yield and chemical properties of soils in semi-arid central Spain. Soil and Tillage Research 36, 45-57.

López-Fando C \& Dorado J (2005) Efecto de distintos sistemas de laboreo sobre las características fisico-químicas de un suelo compactado de la región Central. In: Proceedings 2005 2nd Symposium Control de la Degradación de Suelos, Madrid, Spain, 293-297.

Magurran AE (1988) Ecological Diversity and Its Measurements, Princeton University Press, Princeton, NJ, USA.

McCloskey M, Firbank G, Watkinson AR \& Webb DJ (1996) The dynamics of experimental arable weed communities under different management practices. Journal of Vegetation Science 7, 799-808.
Menalled FD, Gross KL \& Hammond M (2001) Weed aboveground and seedbank community responses to agricultural management systems. Ecological Applications 11, 1586-1601.

Mulugeta D, Stoltenberg DE \& Boerboom CM (2001) Weed species-area relationships as influence by tillage. Weed Science 49, 217-223.

Navarrete L, Fernández-Quintanilla C, Hernanz JL \& SánchezGirón V (2005) Evolución de la vegetación arvense en cultivos de secano. Terralia 50, 24-34.

Parker CJ, Carr MKV, Jarvis NJ, Evans MTB \& Lee VH (1989) Effects of subsoil loosening and irrigation on soil physical properties, root distribution and water uptake of potatoes (Solanum tuberosum). Soil and Tillage Research 13, 267-285.

Pierce FJ, Fortin MC \& Staton MJ (1992) Immediate and residual effects of zone-tillage on soil physical properties and corn performance. Soil and Tillage Research 24, 149-165.

Primot S, Valantin-Morison M \& Makowski D (2006) Predicting the risk of weed infestation in winter oilseed rape crops. Weed Research 46, 22-33.

Shrestha A, Knezevic SZ, Roy RC, Ball-Coelho BR \& Swanton CJ (2002) Effect of tillage, cover crop and crop rotation on the composition of weed flora in a sandy soil. Weed Research 42, 76-87.

SoJka RE, Horne DJ, Ross CW \& BaKer CJ (1997) Subsoiling and surface tillage effects on soil physical properties and forage oat stand and yield. Soil and Tillage Research 40, 125144.

Tørresen KS, Skuterud R, Tandsæ Ther HJ \& Hagemo MB (2003) Long-term experiments with reduced tillage in spring cereals. I. Effects on weed flora, weed seedbank and grain yield. Crop Protection 22, 185-200.

Thomas AG, Derksen DA, Blackshaw RE et al. (2004) A multistudy approach to understanding weed population shifts in medium- to long-term tillage systems. Weed Science 52, 874-880.

Van Gessel MJ, Forney DR, Conner M, Sankula S \& Scott BA (2004) A sustainable agriculture project at Chesapeake Farms: a six-year summary of weed management aspects, yield, and economic return. Weed Science 52, 886-896. 